\title{
Determination of Selected Heavy Metals Content and Health Risk Assessment of Cabbage Cultivated in Elalla Farmland, Mekelle, Ethiopia
}

\author{
Ftsum Gebreyohannes $^{1^{*}} \quad$ Kiros Haile Hagos ${ }^{2}$ \\ 1.Department of Chemistry, College of Natural and Computational Sciences, Aksum University, P.O.Box 1010, \\ Aksum, Ethiopia \\ 2.Department of Chemistry, Faculty of Science, Wolaita Sodo University, P. O. Box 138, \\ Wolaita Sodo, Ethiopia
}

\begin{abstract}
Like other countries in Ethiopia vegetables are vital edible plants which are a crucial part of the human food. One from these vegetables cabbage is a leafy green biennial plant grown as an annual vegetable for its dense leaved heads. The heavy metal content of cabbage may vary on the composition of the water and nature of soil. The study was aimed to determine concentration of selected heavy metals like Cadmium (Cd), Chromium (Cr), $\mathrm{Cupper}(\mathrm{Cu})$, Lead $(\mathrm{Pb})$, Iron $(\mathrm{Fe})$ and Zinc $(\mathrm{Zn})$ were measured in edible portion of cabbage and soils around four sites of cabbage production area in Elalla farmland Mekelle, Tigray, Ethiopia, and the potential health risk of heavy metal contamination to the local population via vegetable consumption, Transfer factor and daily intake of metal was also evaluated. The level of heavy metals in soil and Cabbage vegetable were determined by flame atomic absorption spectrophotometer (FAAS) that uses acetylene as fuel with air. The concentration of Cd $(17.15 \pm 1.26$ to $17.52 \pm 0.24) \mathrm{mg} / \mathrm{Kg}$ and $\mathrm{Zn}(325.10 \pm 6.00$ to $512.86 \pm 3.13) \mathrm{mg} / \mathrm{Kg}$ in the soil sample exceeds from the limit the guideline of agricultural soil and the mean concentrations of $\mathrm{Fe}, \mathrm{Cu}, \mathrm{Pb}$ and $\mathrm{Cr}$ is below the guideline of agricultural soil. The mean concentration of $\mathrm{Pb}(3.060 \pm 0.18$ to $5.982 \pm 0.11), \mathrm{Zn}(144.662 \pm 3.16$ to $173.660 \pm$ 2.18), $\mathrm{Cr}(11.825 \pm 0.18$ to $13.482 \pm 0.37)$ and $\mathrm{Cd}(0.309 \pm 0.01-0.712 \pm 0.06)$ in all study sites of cabbage samples were exceeded the permissible limits set by FAO but $\mathrm{Pb}$ and $\mathrm{Fe}$ are below the permissible limit. The TF calculated were also investigated lower for all metals and for the value of HRI is below 1, according to the present study the result indicates that exposed population is assumed to be safe. As the results show that HRI of contamination in cabbage has less health risk to the consumers.
\end{abstract}

Keywords: - Cabbage, Heavy metals, Health Risk, Health Risk Assessment, Daily Intake Metal

DOI: $10.7176 / \mathrm{CMR} / 11-6-03$

Publication date: August 31st 2019

\section{Introduction}

Vegetables are vital edible plants which are a crucial part of the human food. Feeding of vegetables like cabbage, potato, carrot or beans plays important roles in human nutrition and health, particularly as sources of vitamins, thiamine, niacin, pyridoxine, folic acid, minerals, and dietary fiber and used to convert the fats and carbohydrates in to energy $[1,21]$.

Cabbage (Brassica oleracea) is a leafy green biennial plant grown as an annual vegetable for its dense leaved heads. Cabbage has lower levels of saturated fat and cholesterol and has been recognized as a good source of thiamine, calcium, iron, magnesium, phosphorus, potassium, dietary fiber and manganese [2, 19].

Leafy vegetables like cabbage have the tendency of good absorption of heavy metals from soil. Soils may become contaminated by the accumulation of heavy metals through emissions from the rapidly expanding industrial areas, mine tailings, disposal of high metal wastes, leaded gasoline and paints, land application of fertilizers, animal manures, sewage sludge, pesticides, wastewater irrigation, coal combustion residues, spillage of petrochemicals, and atmospheric deposition [3].Some potentially toxic metals and trace elements like lead, cadmium, chromium, iron, copper and zinc present in agricultural soils enter the human body through the food chain and this could become a significant source of cumulative poisons following continued absorption and bioaccumulation. This contamination of cabbage has been linked to cases of food-borne illness in humans $[4,18]$.

At Elalla which is the river that passes through Mekelle city different municipal wastes are being disposed, cars are being washed, mostly children are using on it for showering and drink from the river and many people are consuming the Cabbage and Spinach vegetables mostly cultivated around that area. However, there were no other studies conducted regarding levels of heavy metals in Cabbage vegetable grown on this study area. Therefore, the study aims to generate baseline information on the level of selected heavy metals $(\mathrm{Cd}, \mathrm{Cr}, \mathrm{Pb}, \mathrm{Cu}, \mathrm{Fe}$ and $\mathrm{Zn}$ ) concentration in soil and edible part of Cabbage vegetables $[5,17]$. 


\section{Materials and Methods}

\subsection{Description of the Study Area}

The study was carried out at around Elalla River farmland which is found to the Northern side of Mekelle city, Tigray, Ethiopia. The city was located 780 kilometers north of the capital city of Ethiopia, Addis Ababa, at a latitude and longitude of $13^{\circ} 29^{\prime} \mathrm{N} 39^{\circ} 28^{\prime} \mathrm{E}$ and $13^{\circ} 29^{\prime} \mathrm{N} 39^{\circ} 28^{\prime} \mathrm{E}$, with an elevation of 2084 meters above sea level. According to Ethiopia 2011 Central Statistical Agency, Mekelle city has an estimated population of 261,200 with density of 86.15 people per square kilometre. The temperature in Mekelle ranges from 11.5 to $30.65{ }^{\circ} \mathrm{C}$ and annual rainfall varies from 24.0 to $486.0 \mathrm{~mm} /$ month [6].

The sampling points of the study area were taken nearby pollution sources and using the global positioning systems reading (GPS), four selected points which are; Dejat abraha building (S1) above the Mekelle-Adigrat main bridge, bridge of Mekelle-Adigrat road (S2), at 05 kebelle police station (S3) in which Wastes disposes the river and some metal work takes place around it and Place where the river leaves the city (S4).

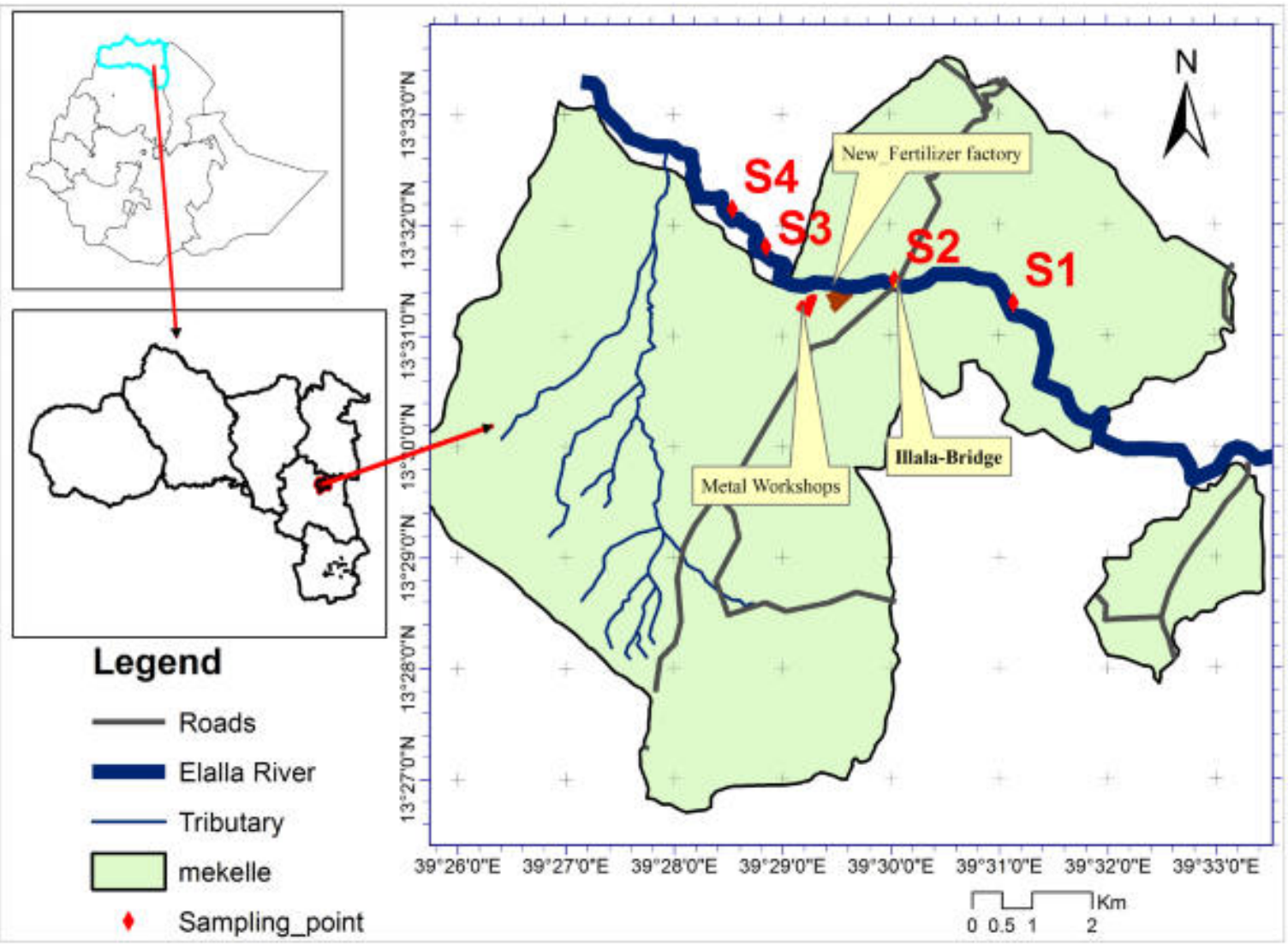

Figure 1. Map of the study area with cabbage and soil sampling sites, Elala farmland, Mekelle [7].

\subsection{Materials and Chemicals}

Drying oven, fast sequential atomic absorption spectrophotometer (Varian AA 240 FS, Australia), hot plate (STUART CB162), analytical balance (LARK LA114), and Fume hood (Uethe-Hangsen D31311, Germany); 70\% $\mathrm{HNO}_{3}$ (BDH, England), $98 \% \mathrm{H}_{2} \mathrm{SO}_{4}$ (RSCL Ltd.Com., India), $37 \% \mathrm{HCl}$ (Riedel-de Häen, Germany) and $30 \% \mathrm{H}_{2} \mathrm{O}_{2}$ (SDSL, Mumbai, India) were used for the analysis. The reagents used were analytical grade and deionized water was used for preparation of solutions $[8,20]$.

\subsection{Sample Collection and Preparations \\ 2.3.1. Sample collection}

Soil samples were taken once at each sampling day from vegetable gardens with near proximity to the River that crosses the city and once had been using the river water for irrigation purpose. The soil samples were taken from center using stainless steel auger soil sampler at a depth of $0-15 \mathrm{~cm}$ after the removal of grassy part. About 1 kilogram of composite soil sample was taken for each site. A total of 4 kilograms of composite soil samples were taken to laboratory in clean and dry polyethylene plastic bags. The collected samples were thoroughly mixed to 
give a representative samples and were dried to constant weight, in an oven to remove excess moisture, then grounded and sieved with 200 mesh $(75 \mu \mathrm{m})$ sieve. The dried samples were kept packed till analysis [9].

About 2 kilograms edible parts of Cabbage vegetable sample were taken from the places in which soil samples were taken and transported to laboratory in clean and dry polyethylene plastic bags. The samples were washed with distilled water to remove dust particles and air dried. The dry vegetable samples were crushed using mortar and pestle. Finally, the powder was packed for heavy metals analysis.

\subsubsection{Digestion producers}

A triplicate sample of $0.5 \mathrm{~g}$ of air-dried ground soil were transferred to the digestive tube; in addition to that $5 \mathrm{ml}$ of concentrated $\mathrm{H}_{2} \mathrm{SO}_{4}, 25 \mathrm{ml}$ of concentrated $\mathrm{HNO}_{3}$ and $5 \mathrm{ml}$ of concentrated $\mathrm{HCl}$ were added consequently. The mixture of three acids with the sample was heated at $200{ }^{\circ} \mathrm{C}$ for one hour in a fuming hood and then cooled to room temperature. After that $20 \mathrm{ml}$ distilled water added and then filtered. The process of digestion was completed. Finally, the mixture were transferred to a $50 \mathrm{ml}$ volumetric flask, filled to the mark and let to settle for at least 15 hours. The filtrates were analyzed for total $\mathrm{Cr}, \mathrm{Fe}, \mathrm{Cu}, \mathrm{Pb}, \mathrm{Zn}$ and $\mathrm{Cd}$ by using FAAS [9]. Reagent blank was passed between every three measurements of replicate samples so as to check for any eventual contamination or abnormal response of equipment.

A triplicate of approximately $0.5 \mathrm{~g}$ of the Cabbage vegetable powder put in to the digestive tube followed by $5 \mathrm{ml}$ of concentrated $\mathrm{HNO}_{3}$ and $3 \mathrm{ml}$ of concentrated $\mathrm{H}_{2} \mathrm{O}_{2}$. The mixture was heated at $160{ }^{\circ} \mathrm{C}$ for 1 hour in a fuming hood and then cooled to room temperature. About $20 \mathrm{ml}$ of distilled water were added and the mixtures were filtered filtered through whatman filter paper number 41. Finally, the mixture were transferred to a $50 \mathrm{ml}$ volumetric flask, filled to the mark and let to settle for at least 15 hours. The filtrates were analyzed for total $\mathrm{Cr}$, $\mathrm{Fe}, \mathrm{Cu}, \mathrm{Pb}, \mathrm{Zn}$ and $\mathrm{Cd}$ by FAAS after the AAS was checked for malfunctioning by passing standard solutions of all the heavy metals to be measured; reagent blank was passed between every three measurements of effluent samples so as to check for any eventual contamination or abnormal response of equipment. Reproducibility of results was regularly checked by carrying out periodic analysis of aliquots collected from one sample and then data were recorded in triplicate [9].

\subsection{Heavy Metals Analysis}

Heavy metals ( $\mathrm{Fe}, \mathrm{Zn}, \mathrm{Cu}, \mathrm{Pb}, \mathrm{Cr}$ and $\mathrm{Cd}$ ) in soil and Cabbage vegetable were determined by flame atomic absorption spectrophotometer (FAAS) that uses acetylene as fuel with air as support at Ezana mining laboratory as described in the manufacturer's instruction manual after the digestion procedure completed. Standard reagents and reagent blanks were prepared freshly when needed. All data were recorded in triplicate while conducting the experiments [10].The instrument working condition and detection limits were shown in Table 1.

Table 1. The FAAS Instrument working condition and limit of detection for heavy metal analysis in soil and vegetable samples of Elalla farmland.

$\begin{array}{ccccccc}\text { Element } & \mathbf{C d} & \mathbf{C r} & \mathbf{C u} & \mathbf{F e} & \mathbf{P b} & \mathbf{Z n} \\ \text { Lamp current }(\mathbf{m A}) & 4 & 7 & 4 & 5 & 5 & 5 \\ \text { Wave length }(\mathbf{n m}) & 228.8 & 357.9 & 324.7 & 248.3 & 217.0 & 213.9 \\ \text { Slit width }(\mathbf{n m}) & 0.5 & 0.2 & 0.5 & 0.2 & 1.0 & 1.0 \\ \text { Instrument detection limit } & 0.002 & 0.006 & 0.003 & 0.006 & 0.010 & 0.001 \\ \text { Soil (mg/kg) MDL } & 1.0 & 1.0 & 1.0 & 1.0 & 1.0 & 1.0 \\ \text { Vegetable (Cabbage) }(\mathbf{m g} / \mathbf{k g}) \text { MDL } & 0.01 & 0.02 & 0.01 & 0.02 & 0.02 & 0.05\end{array}$

\section{Risk assessment}

Transfer factor is expresses by the bioavailability of a metal at a particular position on a species of plant. It was calculated based on the total metal content of the leafy part of the plant by using the formula stated as;

$$
T F=\frac{\text { concentration of metal in edible part of vegetable }}{\text { concentration of metal in soil }} \text { [4]. }
$$

The daily intake of metal is the relative phyto-availability of metal and does not take a possible metabolic removal of the metals into account, but indicates the possible ingestion rate of a particular metal.

$$
D I M=\frac{\mathrm{CMxCFxDIV}}{B W}
$$

Where CM is the concentration of a heavy metal in plant material (mg/ kg), CF is the Conversion Factor (0.085), DIV is the approximate Daily Intake of Vegetables and BW the average body weight $(65 \mathrm{~kg})$ [11].

The health risk index (HRI) was determined as described as follows [12]:

$$
\mathrm{HRI}=\frac{\mathrm{DIM}}{\mathrm{RfDo}}
$$

Where the Reference oral dose (RfDo) is an estimated exposure of metal to the human body per day that has no 
hazardous effect during life time [13]. The value of reference oral doses (RfDo) $\mathrm{mg} / \mathrm{kg} / \mathrm{day}$ for those heavy metals obtained at the present study is summarized in Table 2 below [5].

Table 2. Oral reference doses for heavy metals

$\begin{array}{lllllll}\text { Heavy metal } & \mathrm{Fe} & \mathrm{Zn} & \mathrm{Cu} & \mathrm{Pb} & \mathrm{Cr} & \mathrm{Cd} \\ \text { Values RfDo (mg/kg/day) } & 0.7 & 0.3 & 0.04 & 0.004 & 1.5 & 0.001\end{array}$

Method of data analysis and Validation

Statistical analyses were carried out by using Statistical Package for Social Science (SPSS) for Windows version 16.0. The statistical tools used one-way ANOVA. The results obtained in the present study are reported as mean values (obtained from the nine replications) \pm standard deviation (SD). As the level of heavy metal contamination might vary with sample collection site, ANOVA was used to test the existence of significant difference between means. The significance differences between mean values were analyzed at $95 \%$ confidence level.

\section{Results and Discussion}

Table 3. Heavy metals in soil samples

\begin{tabular}{lcccccc}
\multicolumn{7}{c}{ Metal concentration of soil sample in $\mathbf{~ m g / k g , ~} \mathbf{N}=\mathbf{9}$} \\
Sites & $\mathrm{Fe}$ & $\mathrm{Zn}$ & $\mathrm{Cu}$ & $\mathrm{Pb}$ & $\mathrm{Cr}$ & $\mathrm{Cd}$ \\
S1 & $595.124 \pm 9.55^{\mathrm{b}}$ & $395.57 \pm 8.54^{\mathrm{ab}}$ & $41.54 \pm 1.15^{\mathrm{a}}$ & $1.57 \pm 0.02^{\mathrm{a}}$ & $41.32 \pm 1.51^{\mathrm{a}}$ & $17.15 \pm 1.26^{\mathrm{a}}$ \\
S2 & $805.78 \pm 12.34^{\mathrm{a}}$ & $512.86 \pm 3.13^{\mathrm{a}}$ & $42.61 \pm 1.42^{\mathrm{a}}$ & $2.23 \pm 0.01^{\mathrm{a}}$ & $50.45 \pm 2.16^{\mathrm{a}}$ & $17.40 \pm 1.19^{\mathrm{a}}$ \\
S3 & $867.74 \pm 13.54^{\mathrm{a}}$ & $335.46 \pm 7.80^{\mathrm{b}}$ & $40.20 \pm 2.15^{\mathrm{a}}$ & $2.21 \pm 0.02^{\mathrm{a}}$ & $47.56 \pm 1.48^{\mathrm{a}}$ & $17.52 \pm 0.24^{\mathrm{a}}$ \\
S4 & $598.11 \pm 10.85^{\mathrm{b}}$ & $325.10 \pm 6.00^{\mathrm{b}}$ & $40.17 \pm 0.36^{\mathrm{a}}$ & $1.51 \pm 0.01^{\mathrm{b}}$ & $41.20 \pm 2.41^{\mathrm{a}}$ & $17.24 \pm 1.33^{\mathrm{a}}$ \\
Ewers(1991) & 5000 & 300 & 100 & 100 & 100 & 3.00
\end{tabular}

At $95 \%$ confidence level the mean concentration of all the studied metals were found to be significantly higher in the site S2 \&S3 than site S1 \& S4 which could generally mean there was significant metal pollution due to the loads of different anthropogenic activities. The obtained values ranged from $595.124 \pm 9.55$ to $867.74 \pm$ 13.54 for $\mathrm{Fe}, 325.10 \pm 6.00$ to $512.86 \pm 3.13$ for $\mathrm{Zn}, 42.61 \pm 1.42$ to $40.17 \pm 0.36$ for $\mathrm{Cu}, 1.51 \pm 0.01$ to 2.23 for $\mathrm{Pb}, 41.20 \pm 2.41$ to $50.45 \pm 2.16$ for $\mathrm{Cr}, 17.15 \pm 1.26$ to $17.52 \pm 0.24$ for $\mathrm{Cd}$. The mean concentrations of $\mathrm{Fe}, \mathrm{Cu}$, $\mathrm{Pb}$ and $\mathrm{Cr}$ except $\mathrm{Cd}$ and $\mathrm{Zn}$ considered in the present study were below the guide line value for agricultural soil [4]. As the result from Table 3 shows concentration of $\mathrm{Cd}$ was about 6 times higher than the guideline value. The highest concentrations of the $\mathrm{Cd}$ in the soil sample could be due to coal, diesel, gasoline, incineration of Cdcontaining batteries and plastics, metal alloy production, electroplating, and using of phosphate fertilizers [12]. This excess amount of cadmium accumulation leads health effects like Kidney damage, gastrointestinal effects in form of diarrhoea and vomiting [14].

\subsection{Heavy metals in Cabbage}

Table 4. Concentration of Heavy metals in Cabbage

Site

$\begin{array}{lll} & \mathrm{Pb} & \mathrm{Zn} \\ \text { Site1 } & 3.242 \pm 0.078 & 173.660 \pm 2.18 \\ \text { Site2 } & 5.982 \pm 0.11 & 144.662 \pm 3.16 \\ \text { Site3 } & 3.508 \pm 0.23 & 153.400 \pm 1.15 \\ \text { Site4 } & 3.060 \pm 0.18 & 164.288 \pm 1.10 \\ \text { FAO/WHO } & 0.3(0.1) & 100 \\ \text { Weigert } & 0.30^{*} & 100\end{array}$

\section{Metal Concentration In Cabbage}

$\begin{array}{llll}\mathrm{Cr} & \mathrm{Cd} & \mathrm{Fe} & \mathrm{Cu} \\ 11.825 \pm 0.18 & 0.395 \pm 0.04 & 183.040 \pm 1.31 & 17.006 \pm 0.081 \\ 12.753 \pm 0.47 & 0.712 \pm 0.06 & 172.700 \pm 2.74 & 13.982 \pm 0.14 \\ 12.212 \pm 0.37 & 0.562 \pm 0.53 & 380.720 \pm 3.97 & 13.083 \pm 0.11 \\ 13.482 \pm 0.37 & 0.309 \pm 0.01 & 313.567 \pm 1.01 & 15.823 \pm 0.57 \\ 2.3 & 0.1(0.05) & 425 & 73 \\ 2.30 & 0.20^{*} & 425 & 70.0\end{array}$

$\mathrm{C}$ 425 70.0

Heavy metals are mobile and can easily be taken up by plants in the environment by bioaccumulation and bio magnification. The mean concentration of $\mathrm{Pb}, \mathrm{Zn}, \mathrm{Cr}$ and $\mathrm{Cd}$ in all study sites of cabbage samples was higher than the guideline plants set by Weigert but $\mathrm{Fe}$ and $\mathrm{Cu}$ are below the permissible limit. Singh et al. (2009), Kidu et al. (2015) and Ftsum \& Abraha (2018) reported that $\mathrm{Cd}$ and $\mathrm{Zn}$ concentrations were above the agricultural safe limits of standards in vegetables $[4,5]$. The study suggests that accumulation of heavy metals in food stuff causing potential health risks to consumers in the present study.

As the result indicates the concentration of Cabbage in $\mathrm{S} 2$ was almost 2 times higher than the remaining sites sampling sites. This might be due to the discharge from the road sides, the use of wastewater for irrigation from the bridge in which different vehicles were washed, by the improper disposal of municipal as well as domestic waste and sewage from different garages and construction works of the city in to the irrigated soil [5]. 
Transfer Factor (TF)

Table 5. Transfer Factor of Heavy Metals

$\begin{array}{lllllll}\text { sites } & \text { Fe } & \mathbf{Z n} & \mathbf{C u} & \mathbf{P b} & \mathbf{C r} & \text { Cd } \\ \text { S1 } & 0.310 & 0.438 & 0.415 & 2.065 & 0.293 & 0.023 \\ \text { S2 } & 0.214 & 0.281 & 0.280 & 2.683 & 0.260 & 0.041 \\ \text { S3 } & 0.438 & 0.457 & 0.325 & 1.590 & 0.255 & 0.032 \\ \text { S4 } & 0.523 & 0.505 & 0.400 & 2.026 & 0.317 & 0.018\end{array}$

Variations in transfer factor among the different sites may be attributed to differences in the concentration of metals in the soil and differences in element uptake by different vegetables. Among all studied metals the transfer factor of $\mathrm{Pb}$ was highest for assayed vegetables from the four sampling sites, which showed that $\mathrm{Pb}$ is more mobile than the other metals. Consistent with this suggestion, it was reported that $\mathrm{Pb}$ was retained less strongly by the soil and hence it is more mobile than other metals [15]. The greater the transfer coefficient value than 0.50 , the greater will be the chances of vegetables for metal contamination by anthropogenic activities [4]. When compared with a previous study of Ftsum \& Abraha [5], the cabbage transfer factor of current study showed lower than spinach transfer factors.

Table 6. The DIM from Cabbage grown at around the Elalla farmland

$\begin{array}{ccccccc}\text { Sites } & \text { Fe } & \mathbf{Z n} & \text { DIM }(\mathbf{m g} / \mathbf{k g}) \text { of Cabbage } & \mathbf{C r} & \text { Cd } \\ \text { S1 } & 0.0280 & 0.0270 & 0.0026 & 0.0005 & 0.0018 & 0.0001 \\ \text { S2 } & 0.0260 & 0.0220 & 0.0021 & 0.0009 & 0.0020 & 0.0001 \\ \text { S3 } & 0.0580 & 0.0230 & 0.0020 & 0.0005 & 0.0019 & 0.0001 \\ \text { S4 } & 0.0470 & 0.0250 & 0.0024 & 0.0005 & 0.0021 & 0.0001\end{array}$

The daily intake of $\mathrm{Cd}$ in all four study sites was estimated as $0.0001 \mathrm{mg} / \mathrm{kg}$, which represents approximately $10 \%$ of the RD, established to $0.001 \mathrm{mg} \mathrm{kg}$ of body weight per day. The daily intake was lower than the tolerable daily intake (TDI).

Table 7. Health Risk Index of Heavy metals present in Cabbage.

\begin{tabular}{|c|c|c|c|c|c|c|}
\hline \multirow[b]{2}{*}{ Sites } & \multicolumn{5}{|c|}{ HRI of present study heavy metals } & \multirow[b]{2}{*}{ Cd } \\
\hline & $\mathbf{F e}$ & Zn & $\mathrm{Cu}$ & $\mathbf{P b}$ & $\mathrm{Cr}$ & \\
\hline S1 & 0.040 & 0.090 & 0.065 & 0.125 & 0.001 & 0.100 \\
\hline S2 & 0.037 & 0.073 & 0.052 & 0.225 & 0.001 & 0.100 \\
\hline S3 & 0.083 & 0.077 & 0.050 & 0.125 & 0.001 & 0.100 \\
\hline S4 & 0.067 & 0.083 & 0.060 & 0.125 & 0.001 & 0.100 \\
\hline
\end{tabular}

The HRI for the studied heavy metals presented in Table above $\mathrm{Cr}<\mathrm{Fe}<\mathrm{Cu}<\mathrm{Zn}<\mathrm{Cd}<\mathrm{Pb}$. But for the value of HRI is below 1, the exposed population is assumed to be safe [4]. As the results show that HRI of contamination in cabbage has less health risk to the consumers.

\section{Conclusion}

The present study investigates the heavy metal concentration of cabbage and soil sample on which the cabbage cultivated/ irrigated on it around Elalla River. In addition to this the DIM and health risks assessment of the exposed consumers was assessed and reported. According to the investigation the concentration of heavy metals like $\mathrm{Cd}$ and $\mathrm{Zn}$ in the soil sample exceeds from the limit the guideline of agricultural soil and the mean concentrations of $\mathrm{Fe}, \mathrm{Cu}, \mathrm{Pb}$ and $\mathrm{Cr}$ is below the guideline of agricultural soil. The mean concentration of $\mathrm{Pb}, \mathrm{Zn}$, $\mathrm{Cr}$ and $\mathrm{Cd}$ in all study sites of cabbage samples were exceeded the permissible limits set by $\mathrm{FAO}$ but $\mathrm{Pb}$ and $\mathrm{Fe}$ are below the permissible limit. As the results the study shows that HRI of contamination in cabbage has less health risk to the consumers. But because of the presence of high concentration of Cd which exceeds the permissible limit of FAO in cabbage. The consumers should take a great care they should avoid continuous consumption of cabbage from that area and studies must be conducted in different seasons and periods for the future to level concentration of these heavy metals since.

\section{References}

1. J. Abah, P. Mashebe,S. T. Ubwa and D. D. Denuga. Some Heavy Metals Content of Cabbage and Soil Cultivated in the Bezi Bar Farm Area of Katima Mulilo, Namibia. American Journal of Chemistry, 2014, 4(3): 101-108.

2. U.U. diba, H. J. Chindo, G. B. Bate, Gauje Balli, Anyanwu Stella, Agboun T. D. T. and Umar Shitu. Bioaccummulation of Lead, Chromium, Nickel and Manganese in Brassica oleracea L. Cultivated Along River Galma Basin, Around Dakace Industrial Layout, Zaria, Nigeria. American Association for Sciences and Technology, 2015, 1(5): 65-74.

3. P.S. Okweye. Seasonal variation in physico-chemical parameters and heavy metals assessment in surface 
water of North Alabama. Res. J. Chem. Environ, 2013, 17, 68-115.

4. Kidu Mezgebe, Abraha Gebrekidan,Amanual Hadera, and Yirgaalem Weldegebriel. Assessment of the Distribution and their Health Risk of Trace Metals in Tsaeda Agam River, Mekelle City, Tigray, Northern Ethiopia. J. Environmental \& Analytical Toxicology, 2015, 5(4):

5. Ftsum Gebreyohannes and Abraha Gebrekidan. Health Risk Assessment of Heavy Metals Via Consumption Of Spinach Vegetable Grown In Elalla River. Bull. Chem. Soc. Ethiop, 2018, 32(1), 65-75

6. G. Mebrahtu, S. Zerabruk. Concentration and health implication of heavy metals in drinking water from urban areas of Tigray Region, Northern Ethiopia. Momona Ethiop. J.Sci., 2011. 3, 105-121.

7. Ftsum Gebreyohannes, Abraha Gebrekidan, Amanual Hadera and Samuael Estifanos. Investigations of Physico-Chemical Parameters and its Pollution Implications of Elala River, Mekelle, Tigray, Ethiopia. Momona Ethiopian Journal of Science (MEJS), 2015, 7(2):240-257.

8. Sinha, S. N., \& Biswas, M. (2011). Analysis of physico-chemical characteristics to study the water quality of a lake in Kalyani, West Bengal. Asian Journal of Experimental. Biological Sciences, 2(1), 18-22.

9. O. J. Aderinola and V. Kusemiju. Heavy metals concentration in garden lettuce (Lactuca sativa L.) grown along badagry expressway, Lagos, Nigeria. Transnationa Journal of Science and Technology, 2012, 2(7), 115-130.

10. K. J. Inoti, K. Fanuel, O. George, and O. Paul. Assessment of heavy metal concentrations in urban grown vegetables in Thika Town, Kenya. African Journal of Food Science, 2012, 6(3), 41-46.

11. S. Khan, R. Farooq, S. Khan, M. A. Sadique. Health risk assessment of heavy metals for population via consumption of vegetables. World Appl Sci J, 2009, 6: 1602-1606.

12. M. O. Aremu, B. L. Gav, O. D. Opaluwa, B. O. Atolaiye, P. C. Madu, and D.U. Sangari. Assessment of physicochemical contaminants in waters and fishes from selected rivers in Nasarawa State, NIGERIA. Research Journal of Chemical Sciences, 2011, 1(4), 6-17.

13. Yang, T.; Liu, J. (2012). Health risk assessment and spatial distribution characteristic on heavy metals pollution of Haihe River Basin. J. Environ. Anal. Toxicol. 2:152.

14. M. A. M. Sajib, M. M. Hoque, S. Yeasmin, and M. H. Khatun. A Minerals and heavy metals concentration in selected tropical fruits of Bangladesh. International Food Research Journal, 2014, 21(5): 1731-1736.

15. A. Singh Sharma, R. K. Agrawal and F. M. Marshall). Risk assessment of heavy metal toxicity through contaminated vegetables from waste water irrigated area of Varanasi, India. Tropical Ecology, 2010, 51: 375387.

16. FAO/WHO. Food Additives and Contaminants; FAO/WHO Food Standards Program; ALINORM 01/12A; Joint Codex Alimentarius Commission: Rome, Italy, 2001.

17. V. Angelova, K. Ivanov and R. Ivanova, Effect of Chemical Forms of Lead, Cadmium, and Zinc in Polluted Soils on Their Uptake by Tobacco, Journal of Plant Nutriton, 2004, 27, 757-773.

18. B. Buszewski, A. Jastrzębska, T. Kowalkowski and A. Górna-Binkul. Monitoring of Selected Heavy Metals Uptake by Plants and Soils in the Area of Torun, Poland. Polish Journal of Environmental Studies, 2000, 9 , 511-515.

19. V. Jena and S. Gupta, Study of Heavy Metal Distribution in Medicinal Plant Basil. Environmental and Analytical Toxicology, 2012, 2, 1-3.

20. S. Nookabkaew, N. Rangkadilok and J. Satayavivad, Determination of Trace Elements in Herbal Tea Products and Their Infusions Consumed in Thailand. Journal of Agriculture and Food Chemistry, 2006, 54, 6939-944.

21. B. Buszewski, A. Jastrzębska, T. Kowalkowski and A. Górna-Binkul. Monitoring of Selected Heavy Metals Uptake by Plants and Soils in the Area of Toruń, Poland. Polish Journal of Environmental Studies, 2000, 9 , 511-515. 